\title{
DO PRICES CONVERGE AMONG INDONESIAN CITIES? AN EMPIRICAL ANALYSIS
}

\author{
Bhushan Praveen Jangam* and Vaseem Akram** \\ *Indian Institute of Technology, Hyderabad, India. Email: jbpraveen1@gmail.com \\ **Indian Institute of Technology, Hyderabad, India. Email: akramvaseem001@gmail.com
}

\begin{abstract}
We investigate consumer price convergence for 82 Indonesian cities using monthly data from 2014 to 2019. To do so, we employ recent techniques of club convergence and weak sigma convergence. The results reveal, first, consumer price divergence, implying price rigidities across the cities. Second, we find four clubs, suggesting that Indonesian cities converge along four unique transition paths. Third, we find weak evidence of consumer price convergence, suggesting that prices among Indonesian cities adjust, but not freely. Policy should therefore consider unique convergence paths for each club to promote stronger consumer price convergence.
\end{abstract}

Keywords: Club convergence; Weak sigma convergence; Price convergence; Indonesian cities. JEL Classifications: C23; E31.

Article history:

Received : June 24, 2019

Revised : October 2, 2019

Accepted : October 11, 2019

Available online : October 15, 2019

https://doi.org/10.21098/bemp. v22i3.1152 


\section{INTRODUCTION}

Convergence analysis is one of the major elements in economic analysis. Crosssectional units exhibit convergence behavior when their variation diminishes over time (Hotelling, 1993). Price convergence is associated with the law of one price (LOOP). LOOP refers to the notion that, in an efficient market, the price of identical goods must be same when expressed in a common currency. Evidence of LOOP is still subject to debate and is a puzzle in macroeconomics. Many studies have investigated price convergence across countries, but the outcome remains ambiguous.

Broadly, the literature on price convergence can be categorized into four strands. The first strand of research validates the existence of price convergence (Hill, 2004; Allington et al., 2005; Afin, 2006; Faber and Stokman, 2009; Fischer, 2010; Guerreiro and Mignon, 2013; Gheorghe and Vasile, 2015; Kim, and Ryu, 2015; Saygili, 2017; and Hałka and Leszczynska-Paczesna, 2018), whereas the second strand finds evidence of price divergence (Isard, 1977; Engel and Rogers, 1996; Coleman and Daglish, 1998; Asplund and Friberg, 2001; Lutz, 2004; Cuaresma et al., 2007; Fischer, 2012; Montañés and Olmos, 2013; Wood et al., 2016; Churchill et al., 2018). The third strand of literature focuses on the decline in price dispersion and rising price convergence (Engel and Rogers, 2004; Rogers, 2007; Wimanda, 2009; Arruda et al., 2018). The fourth strand finds mixed evidence of price convergence, with studies finding convergence in certain countries and divergence in others (Parsley and Wei, 1996; Sonora, 2008; Chmelarova and Nath, 2010; Yazgan and Yilmazkuday, 2011; Tsai I-Chun, 2018).

Through disaggregated analysis, associated problems such as factor market rigidities and exchange rate volatility can be disregarded (Parsley and Wei, 1996). There are few studies at the disaggregated level. For instance, Morshed et al. (2006), Das and Bhattacharya (2018), and Kitenge and Morshed (2019) examine price convergence at the regional level in India. A similar issue in US cities is discussed by Cecchetti et al. (2000), Huang et al. (2012), Kim and Rous (2012), Hegwood and Nath (2013), Montañés and Olmos (2013), Wood et al. (2016). Churchill et al. (2018) examine housing price convergence in Australian cities and find divergence in housing prices across the Australian states. Although Wimanda (2009) and Varela et al. (2013) have explored the issue of price convergence at the sectoral and product levels in Indonesia, ${ }^{1}$ evidence of consumer price convergence across Indonesian cities is scant. Moreover, Wimanda and Varela et al. (2013) examine LOOP based on two neoclassical concepts of convergence: (i) absolute (or beta) convergence, which states that the economic growth of a poor country/region will converge to that of a rich country-considered a necessary condition rather than a sufficient one-and (ii) sigma convergence, which refers to a reduction in the variation across countries over time (Quah, 1993).

The present study thus fills this research gap by investigating consumer price convergence in Indonesian cities, among which there is vast disparity in consumer prices (Wimanda, 2009). Indonesia is a massive archipelago whose cities are mutually interdependent for supplies. This has led to the greater integration

1 Maryaningsih and Savitri (2014), Purwono et al. (2018), and Rath (2019), among others, also examine non-price convergence. 
of distribution and transport systems to guarantee adequate and fair supply distribution. In 2012, national shipping fleets in Indonesia grew by 7\%, which mostly helped domestic freight. Additionally, there has been an increase in the number of sea freight license holders in recent years. ${ }^{2}$ Despite improvement in the distribution and growth of transport services across the Indonesian cities, considerable price disparities remain a challenging issue. As Tirtosuharto and Adiwilaga (2013) mention, inflation in Indonesia is more volatile compared to its border countries, due to frequent disruptions in food supplies and distribution. Moreover, evidence of substantial consumer price disparities across Indonesian regions has been noted, with differences in transportation costs, levels of development, the logistical costs of goods, non-traded products, firm monopolies, labor market segmentation, informational asymmetries, and productivity (e.g., Tirtosuharto and Adiwilaga, 2013; Varela, et al., 2013). ${ }^{3}$ Moreover, Tirtosuharto and Adiwilaga (2013) state that inflation differs (or changes in price differ) from region to region, with a huge disparity across eastern Indonesian, Java, Jakarta, and Sumatra. The findings for Sumatra and Eastern Indonesian regions are more uneven compared to the other regions. According to the Indonesia investment database, ${ }^{4}$ the changes in prices in Indonesia are greater than in other emerging market nations. The Consumer Price Index (CPI) of emerging market nations rose by 5\% from 2005 to 2014 , whereas in Indonesia it increased by around $8.5 \%$. However, since 2015, there has been little improvement in Indonesia's inflation rate, and there is still vast disparity in consumer prices across Indonesian cities, despite the decentralization process, and it remains a contentious issue (Wimanda, 2009; Varela et al., 2013). Examination of LOOP or the convergence of the CPI is therefore vital for Indonesian cities for greater market integration and fair supply distribution. The main concept of LOOP is that, if the prices in one city increase considerably compared to other cities, market forces will equalize them across cities (Obstfeld and Rogoff, 2000). However, because of the rigidities pointed out above, the prices do not adjust.

Although considerable research has been performed on price convergence or LOOP across countries at an aggregate level, there are no studies in the context of Indonesian cities except for that of Wimanda (2009), who examines the issue of price convergence at the product level. More specifically, Wimanda studies price variability and convergence using the price index data of 35 products in 45 cities from 2002 to 2008. Our paper differs from Wimanda's in three ways. First, it examines consumer price variability and the prospect of consumer price convergence for 82 Indonesia cities by considering the CPI of each city, unlike Wimanda's study, which considers only product price convergence. Investigation of CPI convergence at the city level is vital, because of the vast disparities and variability observed (see Figures 1 and 2 and Table 1). Cities such as Batam, Kudos, Cilacap, Tanjung Pandan, Metro, Bengkulu, Tembilahan, Tual, Tarakan,

2 Source: Ministry of Transportation of the Republic of Indonesia.

3 For a good discussion of regional price disparities in Indonesia, see Tirtosuharto and Adiwilaga (2013).

${ }_{4}^{4}$ For more details, see https://www.indonesia-investments.com/finance/macroeconomic-indicators/ inflation-in-indonesia/item254. 
and Padang have higher consumer prices compared to the others. Table 1 shows that the standard error is higher for Sibolga, Medan, Bengkulu, Pangkal Pinang, Tual, Tarakan, Pontianak, and Serang. This implies that these cities have greater variation in their CPIs. The same implication about disparities in consumer price is noted by Tirtosuharto and Adiwilaga (2013).

\section{Figure 1. Bar Plots of Mean of Consumer Price Index Across Cities}

This figure plots the mean of the consumer price index for each Indonesian city for which we have data. There is a sample of 82 cities in our analysis.

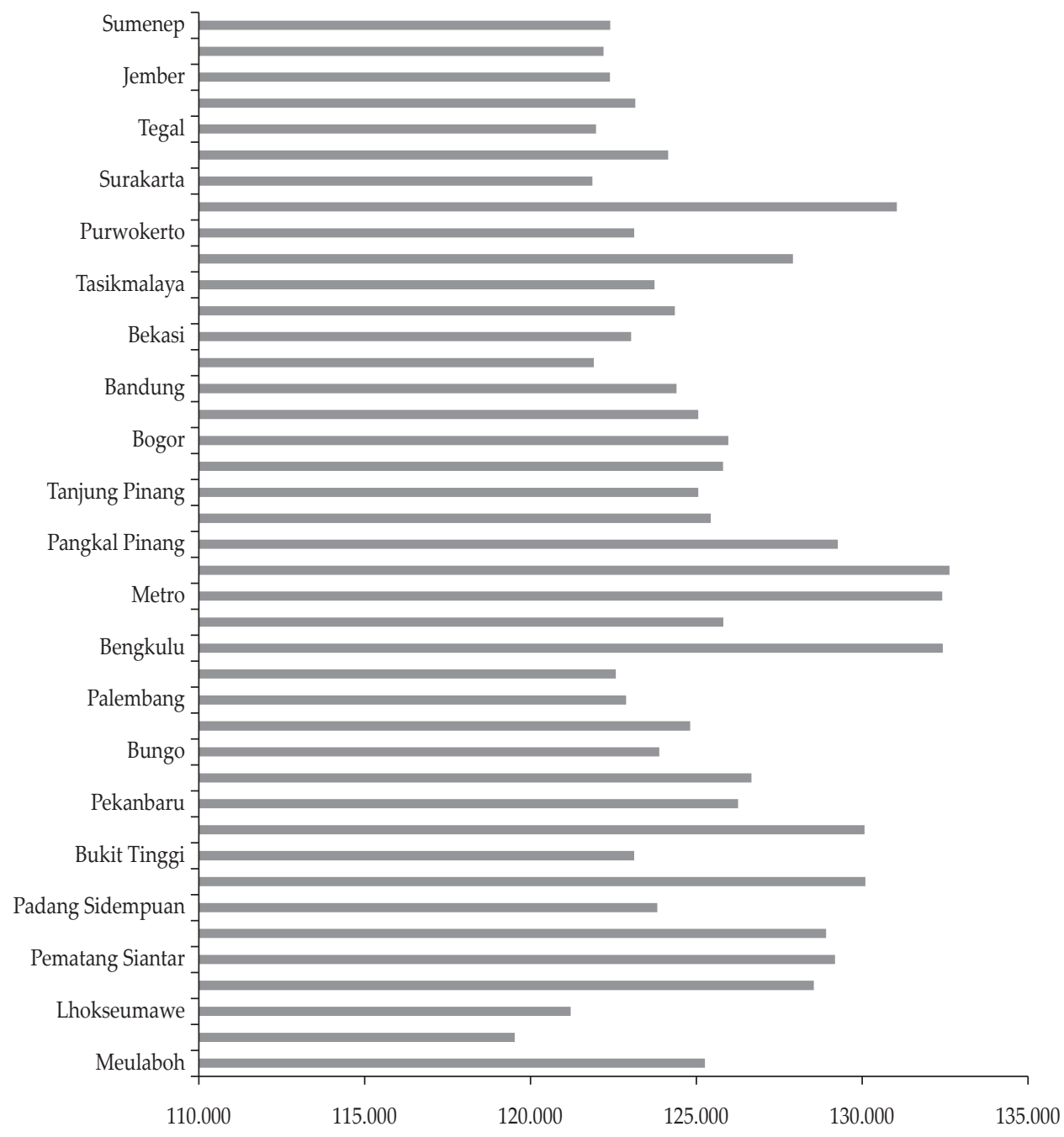


Figure 2. Bar Plots of Mean of Consumer Price Index Across Cities (continued) See notes to Figure 1.

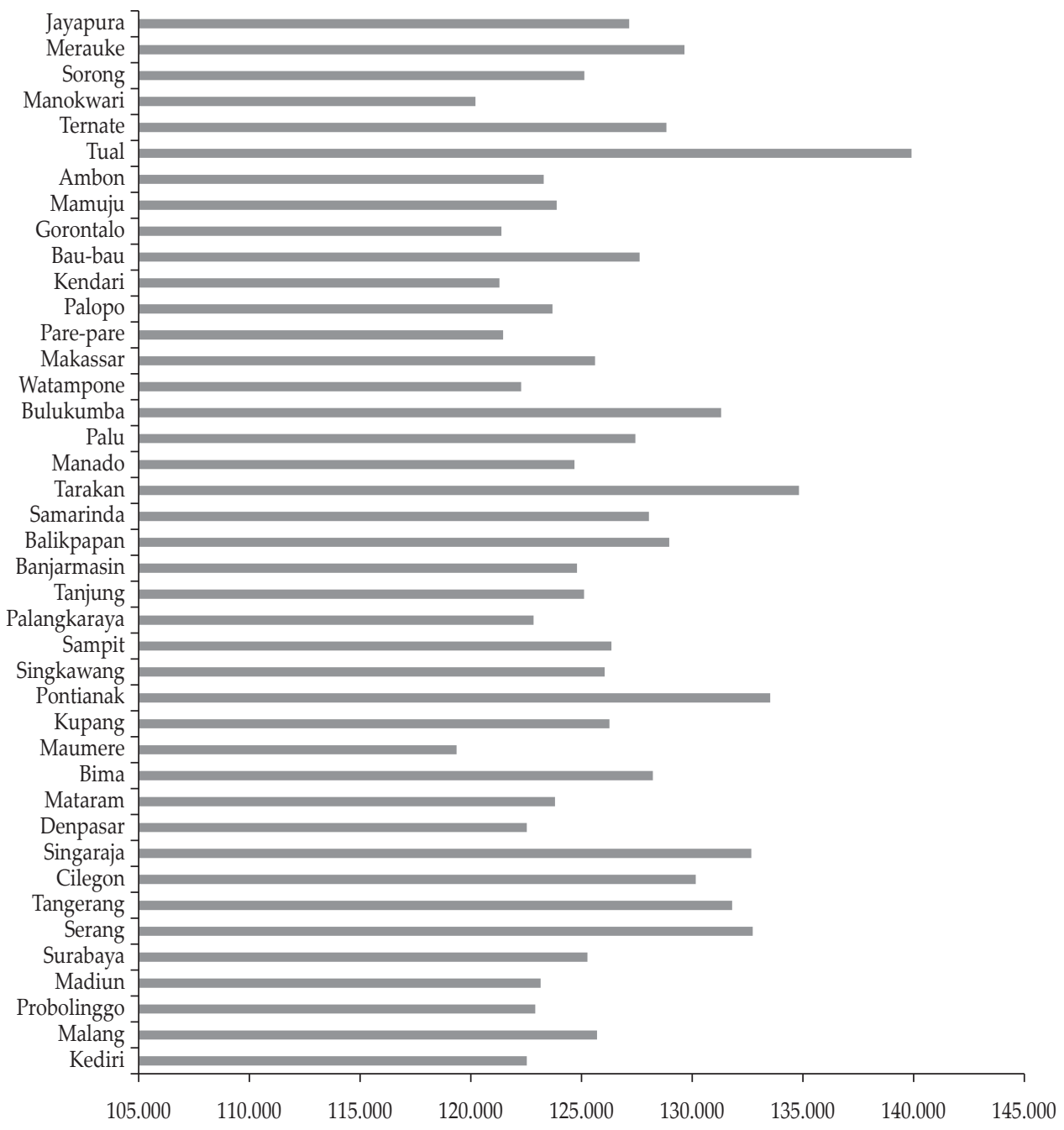


Table 1.

\section{Summary Statistics Results}

This table reports the summary statistics of prices across Indonesian cities for the period 2014 to 2019. From mean, standard deviation (Std. Dev), minimum (min.) and maximum (max.) values, allow us to observe the dispersion or heterogeneity across the Indonesian cities.

\begin{tabular}{|c|c|c|c|c|c|c|c|c|c|}
\hline Cities & Mean & $\begin{array}{l}\text { Std. } \\
\text { Dev }\end{array}$ & Min & $\operatorname{Max}$ & Cities & Mean & $\begin{array}{l}\text { Std. } \\
\text { Dev. }\end{array}$ & Min & Max \\
\hline Ambon & 123.3 & 6.71 & 108.58 & 134.45 & Medan & 128.91 & 9.56 & 111.57 & 146.7 \\
\hline Balikpapan & 128.97 & 8.96 & 111.85 & 142.36 & Merauke & 129.66 & 8.5 & 111.84 & 141.02 \\
\hline Banda Aceh & 119.52 & 6.69 & 107.26 & 130.34 & Metro & 132.41 & 6.71 & 112.58 & 143.08 \\
\hline Bandar Lampung & 125.81 & 8.47 & 109.89 & 139.55 & Meulaboh & 125.26 & 7.02 & 112.05 & 138.22 \\
\hline Bandung & 124.4 & 7.95 & 109.87 & 137.97 & Padang & 130.1 & 8.73 & 113.48 & 144.55 \\
\hline Banjarmasin & 124.8 & 8.85 & 108.22 & 138.87 & Padang Sidempuan & 123.82 & 7.65 & 110.39 & 136.97 \\
\hline Banyuwangi & 122.2 & 5.81 & 111.04 & 131.46 & Palangkaraya & 122.84 & 7.02 & 109.63 & 133.87 \\
\hline Batam & 125.43 & 9.2 & 109.24 & 140.33 & Palembang & 122.88 & 7.81 & 108.41 & 134.44 \\
\hline Bau-bau & 127.62 & 7.82 & 109.84 & 139.31 & Palopo & 123.69 & 8.22 & 108.84 & 136.56 \\
\hline Bekasi & 123.03 & 7.35 & 110.15 & 136.95 & Palu & 127.43 & 9.25 & 110.78 & 144.15 \\
\hline Bengkulu & 132.43 & 10.26 & 112.57 & 147.98 & Pangkal Pinang & 129.26 & 10.63 & 110.52 & 146.22 \\
\hline Bima & 128.22 & 8.05 & 113.35 & 141.05 & Pare-pare & 121.46 & 6.77 & 108.21 & 132.6 \\
\hline Bogor & 125.96 & 8.45 & 111.73 & 140.54 & Pekanbaru & 126.25 & 8.61 & 110.92 & 141.09 \\
\hline Bukit Tinggi & 123.12 & 7.11 & 109.55 & 135.18 & Pematang Siantar & 129.18 & 8.71 & 113.32 & 143.12 \\
\hline Bulukumba & 131.3 & 8.22 & 116.06 & 144.46 & Pontianak & 133.52 & 10.46 & 111.78 & 148.97 \\
\hline Bungo & 123.88 & 7.73 & 109.75 & 137.75 & Probolinggo & 122.91 & 5.59 & 112.23 & 131.59 \\
\hline Cilacap & 127.91 & 8.01 & 112.9 & 140.58 & Purwokerto & 123.12 & 6.95 & 110.49 & 134.79 \\
\hline Cilegon & 130.16 & 9.89 & 111.98 & 145.91 & Samarinda & 128.05 & 8.17 & 113.78 & 140.25 \\
\hline Cirebon & 121.9 & 6.32 & 110.11 & 131.94 & Sampit & 126.35 & 9.24 & 109.94 & 141.16 \\
\hline Denpasar & 122.52 & 7.23 & 109.14 & 134.06 & Semarang & 124.14 & 7.19 & 110.39 & 136.02 \\
\hline Depok & 124.35 & 7.27 & 111.53 & 137.36 & Serang & 132.73 & 10.34 & 112.98 & 149.23 \\
\hline Dumai & 126.66 & 8.35 & 110.67 & 139.49 & Sibolga & 128.54 & 10.32 & 110.37 & 148.33 \\
\hline Gorontalo & 121.38 & 7.32 & 107.91 & 133.36 & Singaraja & 132.68 & 9.02 & 114.67 & 146.5 \\
\hline Jakarta & 125.8 & 7.84 & 110.75 & 138.7 & Singkawang & 126.04 & 8.99 & 109.14 & 139.61 \\
\hline Jambi & 124.81 & 7.43 & 111.26 & 137.3 & Sorong & 125.13 & 8.14 & 108.43 & 136.75 \\
\hline Jayapura & 127.15 & 8.97 & 111.64 & 142.49 & Sukabumi & 125.06 & 7.34 & 111.29 & 136.72 \\
\hline Jember & 122.39 & 6.53 & 110.65 & 132.5 & Sumenep & 122.4 & 6.74 & 109.42 & 132.17 \\
\hline Kediri & 122.53 & 5.59 & 111.91 & 130.77 & Surabaya & 125.26 & 8.08 & 110.47 & 137.16 \\
\hline Kendari & 121.29 & 7.36 & 107.34 & 135.35 & Surakarta & 121.87 & 6.53 & 109.5 & 132.39 \\
\hline Kudus & 131.05 & 8.18 & 116.25 & 144.56 & Tangerang & 131.81 & 9.63 & 111.46 & 146.86 \\
\hline Kupang & 126.26 & 7.39 & 111.39 & 136.34 & Tanjung & 125.12 & 8.03 & 109.57 & 136.2 \\
\hline Lhokseumawe & 121.21 & 7.58 & 107.19 & 132.5 & Tanjung Pandan & 132.63 & 9.17 & 114.68 & 147.46 \\
\hline Lubuk Linggau & 122.57 & 8.19 & 106.76 & 134.66 & Tanjung Pinang & 125.05 & 6.87 & 111.87 & 136.23 \\
\hline Madiun & 123.15 & 7.44 & 109.71 & 134.52 & Tarakan & 134.83 & 10.04 & 113.64 & 150.66 \\
\hline Makassar & 125.62 & 9.35 & 108.65 & 139.94 & Tasikmalaya & 123.73 & 7.54 & 109.2 & 134.58 \\
\hline Malang & 125.7 & 7.74 & 111.03 & 137 & Tegal & 121.97 & 7.74 & 107.62 & 134.25 \\
\hline Mamuju & 123.88 & 7.75 & 108.75 & 133.78 & Tembilahan & 130.07 & 7.66 & 115.63 & 144.3 \\
\hline Manado & 124.68 & 7.98 & 109.05 & 140.02 & Ternate & 128.83 & 8.19 & 111.57 & 141.42 \\
\hline Manokwari & 120.21 & 8.45 & 106.28 & 136.46 & Tual & 139.9 & 13.98 & 112.53 & 160.83 \\
\hline Mataram & 123.8 & 7.21 & 110.53 & 135.11 & Watampone & 122.28 & 7.64 & 108.28 & 134.96 \\
\hline Maumere & 119.35 & 5.74 & 108.76 & 127.33 & Yogyakarta. & 123.15 & 7.01 & 110.77 & 134.27 \\
\hline
\end{tabular}


Second, Wimanda (2009) considers only 45 cities and determines whether the product prices of poor cities converge toward those of prosperous cities, using the absolute and sigma notion of convergence, which seem to have been ruled out by the data in recent years, as discussed above. According to the neoclassical convergence approach (absolute or sigma), a steady state can be achieved if the consumer prices of all the cities increase at the same rate, which is not the case in the 83 Indonesian cities. Thus, we differ from Wimanda by relaxing this assumption, such that the cities do not need to have the same price level but, instead, the relative prices need to be the same along a transition path toward steady state. Third, our paper complements Wimanda's by investigating the speed of convergence (or the transition path).

To achieve the goals of this paper, we apply the panel club convergence of Phillips and Sul (2007, 2009, hereafter PS) and the weak sigma convergence test of Kong et al. (2019). We consider the PS approach for the following reasons: (i) It addresses the issue of panel heterogeneity, (ii) it employs a nonlinear time-varying factor, (iii) it is ideal for the detection of asymptotic co-movement in the presence of a unit root, and (iv) it splits the full sample into clubs based on a clustering algorithm. Further, the weak sigma convergence test is useful when the panel data do not involve stochastic or divergent deterministic trends. The results derived from these tests show no evidence of overall consumer price convergence among Indonesian cities, unlike Wimanda's (2009) study; rather, we find four clubs, suggesting four different transition paths. Further, we find evidence of weak consumer price convergence, suggesting that consumer prices among Indonesian cities adjust, but not freely. These findings suggest that a single policy might not work properly in Indonesian cities, contrary to Wimanda's (2009) product price proposition. Thus, policy should be designed based on clubs to achieve stronger consumer price convergence.

The remainder of the paper is organized as follows. Section II describes the methodology and data. Sections III and IV present the empirical results and conclusions, respectively.

\section{METHODOLOGY AND DATA}

\section{A. Sources of Price Variability}

The price variability framework is based on the concept of purchasing power parity (PPP). Engel (1993) claims that deviations from LOOP across cities are the primary reason for the failure of PPP. This framework helps understand the importance of national borders in the integration of markets. Engel and Rogers (2001) generalize Engel's (1993) price variability approach to understand the importance of PPP violation across cities. They focus on two sources of variability: (i) variability in individual prices across cities and (ii) variability of all product prices across cities. Engel and Rogers argue that LOOP will hold if the variability of each individual price across cities is less than the variability of prices of all products in each individual city. In other words, a relative LOOP will be validated if the ratio between the variability in the prices of all products in the same city and the variability in the prices of the same product across cities is greater than one. 
Consider, for example, two goods $A$ and $B$ in two localities $x$ and $y$. Let $P$ and $p$ be the reflection of the overall price and the price of a specific good, respectively. Then, the total price in locality $x$ is given by

$$
P^{x}=\alpha p_{A}^{x}+(1-\alpha) p_{B}^{x}
$$

and, similarly, the overall price in locality $y$ is given by

$$
P^{y}=\gamma p_{A}^{y}+(1-\gamma) p_{B}^{y}
$$

where $\alpha$ and $\gamma$ are the proportions of good $A^{\prime}$ s price in localities $x$ and $y$, respectively. The difference between equations (1) and (2) results in

$$
\begin{aligned}
& P^{x}-P^{y}=\alpha p_{A}^{x}+(1-\alpha) p_{B}^{x}-\gamma p_{A}^{y}-(1-\gamma) p_{B}^{y} \\
& P^{x}-P^{y}=\alpha\left(p_{A}^{x}-p_{A}^{y}\right)+(1-\alpha)\left(p_{B}^{x}-p_{B}^{y}\right)+(\alpha-\gamma)\left(p_{A}^{y}-p_{B}^{y}\right)
\end{aligned}
$$

or

$$
P^{x}-P^{y}=\gamma\left(p_{A}^{x}-p_{A}^{y}\right)+(1-\gamma)\left(p_{B}^{x}-p_{B}^{y}\right)+(\alpha-\gamma)\left(p_{A}^{x}-p_{B}^{x}\right)
$$

There are two types of terms in equations (4) and (5): the first compares the price of the same good ( $A$ or $B$ ) in the two different cities $x$ and $y$ and the second compares the prices of different goods $(A$ and $B)$ in the same location $(x$ or $y)$.

If LOOP holds, then the prices of similar goods converge across different cities, that is, there is a tendency for $p_{A}{ }^{x}=p_{A}{ }^{y}$ and $p_{B}{ }^{x}=p_{B}{ }^{y}$. Then, $V\left(p_{A}{ }^{x}-p_{A}{ }^{x}\right)$ will be low and $V\left(p_{A}{ }^{x}-p_{B}{ }^{x}\right)>V\left(p_{A}{ }^{x}-p_{A}{ }^{y}\right)$, where $V$ stands for the variability. This expression indicates that the volatility of relative prices in the same city is higher than the volatility of the price of the same good across cities. Moreover, if the price of an individual good is sticky across cities, then one can rewrite the expression as $V\left(p_{A}{ }^{x}-p_{B}{ }^{x}\right)>V\left(p_{A}{ }^{x}-p_{A}{ }^{y}\right)$.

Further, following Engel and Rogers (2001), we can write the ratio of $r_{i}^{k}$ as $r_{i}^{k}=\frac{\left(\frac{1}{l-1}\right) \sum_{n=1, n \neq i}^{l} s d\left(\Delta p_{i, t}^{k}-\Delta p_{n, t}^{k}\right)}{\left(\frac{1}{h-1}\right) \sum_{m=1, m \neq i}^{h} s d\left(\Delta p_{i, t}^{k}-\Delta p_{n, t}^{m}\right)}$, where $s d$ stands for the standard deviation, or variability; $l$ and $h$ denote the number of products and cities, respectively; and $p_{i, t}^{k}$ is the price of good $i$ at time $t$ at location $k$. From this expression, three inferences can be drawn when the denominator is small: (i) When LOOP holds, the differences between the prices of good $B$ in the two locations will be small, (ii) the difference will be constant if the price of good $B$ at location $x$ is proportional to the price of good $B$ at location $y$, and (iii) the price of good will be mostly unchanged in both localities. ${ }^{5}$ Our study focuses on whether these variabilities across cities in Indonesia diminish and converge towards LOOP.

5 A detailed framework can be found in Engel and Rogers (2001). 


\section{B. Coefficient of Variation (CV)}

Numerous studies (e.g., Dalgaard and Vastrup, 2001; Miketa and Mulder, 2005; Liddle, 2009, 2010; Ram, 2017; Rath, 2019; Rath and Akram, 2019) have examined convergence through the CV. For preliminary purposes, this study analyzes variability considering the $\mathrm{CV}$. Examining the $\mathrm{CV}$ provides a broad idea of whether price variability has been declining over the years across cross sections. The CV can be written as

$$
C V=\frac{\sigma}{\mu} \times 100
$$

where $\sigma$ and $\mu$ denote the standard deviation and mean, respectively, of the consumer price across countries. We say there is convergence if the ratio of the standard deviation and mean decline over the years, and vice versa.

\section{Absolute Convergence}

In the next stage, we check for consumer price convergence by applying various panel techniques, such as pooled regression, a fixed dynamic panel model, and the system generalized method of moments (GMM) model of Arellano and Bover (1995) and Blundell and Bond (1998). We choose the system GMM over the differenced GMM model because the latter suffers from sample bias. The system GMM model corrects sample bias by including the momentum condition.

There are two advantages to using a dynamic panel data model. First, it includes a complete set of city-specific effects as exogenous variables, and the fixed effects specification avoids the omitted variable bias, which arises due to crosscity heterogeneity. Second, it takes into account the possible endogeneity of the independent variables (Castellacci and Archibugi, 2008; Narayan et al., 2011). In this paper, we conduct a cross-city analysis of CPIs. The model can be explained with the following equation:

$$
\ln \left(P_{i, t}\right)-\ln \left(P_{i, t-1}\right)=\beta \ln \left(P_{i, t-1}\right)+\mu_{i}+\lambda_{t}+\varepsilon_{i, t}
$$

for Indonesian city $i=1,2, \ldots, 82$ and time $t=1,2, \ldots, 68$, where $P_{i t}$ stands for the CPI, $\beta$ is the coefficient of the CPI to be estimated, $\mu_{i}$ is a city-specific effect, $\lambda_{t}$ is a time-specific constant, and $\varepsilon_{i, t}$ is an error term. A negative and statistically significant coefficient of $\beta$ suggests absolute consumer price convergence, and a positive and significant coefficient suggests consumer price divergence. Equation (7) can be rewritten as

$$
p_{i, t}=\eta y_{i, t-1}+\mu_{i}+\lambda_{t}+\varepsilon_{i, t}
$$

where $\eta=1+\beta$ and $p_{i, t}=\ln P_{i, t}$. We remove individual country- and time-specific effects $\mu_{i}$ and $\lambda_{t}$, respectively, which can be done by differencing equation (8), as follows: 


$$
p_{i, t}-p_{i, t-1}=\eta\left(p_{i, t-1}-p_{i, t-2}\right)+\left(\varepsilon_{i, t}-\varepsilon_{i, t-1}\right)
$$

We do not estimate this equation using the Ordinary Least Squares (OLS) method, because the lagged dependent variables are correlated with the composite error through period $t-1$. Therefore, following Arellano and Bond (1991), we use all past values of the explanatory variables as instruments in the regression.

\section{PS Technique}

In the next stage, we apply the PS technique to determine club convergence. This technique is widely used in the literature, due to its uniqueness and superiority over conventional convergence tests. The PS test allows for a non-time-varying factor model. It forms clubs endogenously in a panel, using clustering algorithms, to estimate the relative convergence by averaging the cross section, unlike absolute convergence. The other feature of the PS test is that it does not depend upon a stationary/non-stationarity series, and it identifies multiple steady states. The test corrects the biases that arise from unit root properties and considers both individual-specific and common components.

In our case, the CPI is denoted by $P_{i t}$ for city $i=1,2, \ldots, 82$ and time $t=1,2 \ldots, 68$. One factor model proposed by PS is

$$
P_{i t}=\delta_{i} \mu_{t}+u_{i t}
$$

where $\delta_{i}$ denotes the idiosyncratic term that indicates the gap between systematic factors $\left(P_{i t}\right)$ and common factors $\left(\mu_{t}\right) ; \mu_{t}$ is the accrued behavior of $P_{i t^{\prime}}$ which affects city behavior; and $u_{i t}$ is the white noise term. Thus, equation (10) verifies the progression for individual $P_{i t}$ values in relation to common factors, utilizing two idiosyncratic elements, namely, $\delta_{i}$ and $u_{i t}$. Next, we divide the $P_{i t}$ series into transitory components $\left(B_{i t}\right)$ and systematic components $\left(G_{i t}\right)$ :

$$
P_{i t}=\left(\frac{G_{i t}+B_{i t}}{\mu_{t}}\right) \mu_{t}=\delta_{i t} \mu_{t}, \quad \forall i, t
$$

where $\mu_{t}$ stands for a common steady-state trend function comprised of stochastic and deterministic components, and $\delta_{i t}$ denotes an idiosyncratic term that includes city-specific and time effects. In other words, the coefficients of $\delta_{i t}$ indicate the common factor share of $\mu_{t}$ for each individual in a panel. PS further state that convergence is not a static process, but a dynamic one. Furthermore, $\delta_{i t}$ provides information about the transition paths that can be tested by the relative temporal evolution of $\delta_{i t}$.

The PS methodology does not make any assumptions about the parameters of $\mu_{t^{\prime}}$ but factors it out by emphasizing $\delta_{i t}$ which is not directly observable from equation (11), because there are fewer unknown parameters than observations. Hence, PS consider a semiparametric form to construct a formal test for convergence, which 
they argue removes unobservable heterogeneity by rescaling and averaging the panel:

$$
h_{i t}=\frac{P_{i t}}{\frac{1}{N} \sum_{i=1}^{N} P_{i t}}=\frac{\delta_{i t}}{\frac{1}{N} \sum_{i=1}^{N} \delta_{i t}}
$$

where $h_{i t}$ illustrates the transition path with respect to the mean of the panel. The term $h_{i t}$ varies across individuals in short periods but converges in the long run as $t \rightarrow \infty$ if $h_{i t} \rightarrow 1$, for all $i$. This occurs in long periods when the individual variance of $h_{i t}$ tends to zero. The required equation for club convergence with time-varying coefficients $\delta_{i t}$ is

$$
\delta_{i t}=\delta_{i}+\sigma_{i t} \xi_{i t}
$$

where $\sigma_{i t}=\frac{\sigma_{i}}{L(t) t^{\alpha}}, \sigma_{i}>0, t \geq 1$, and $\xi_{i t}$ is weakly reliant over $t$ and independent and identically distributed $(0,1)$ over $i$. According to PS the "null hypothesis" is convergence. The regression model is given as follows:

$$
\log \left(\frac{H_{1}}{H_{t}}\right)-2 \log L(t)=\hat{c}+\hat{b} \log t+\widehat{u}_{t}
$$

where $t=[r T],[r T]+1, \ldots, \mathrm{T}$, with $r>0 ; H_{1} H_{t}$ indicates the individual variance ratio; $L(t)=\log (t+1)$ is used in equation (14); PS choose $r=0.33$ for $T \leq 50 ; H_{t}=\frac{1}{N} \sum_{i=1}^{N}\left(h_{i t}-1\right)^{2}$ ; and $\widehat{b}=2 \widehat{\alpha}$, with $\widehat{\alpha}$ denoting the least squares parameter of $a$. In the case of the null hypothesis, $\log \left(\frac{H_{1}}{H_{t}}\right)$ diverges if $a>0$ or $a=0$, and convergence is verified by a one-sided $t$-test and asymptotically follows a standard normal distribution. One can reject the null of convergence at the $5 \%$ level of significance if $t_{\hat{b}} \leq-1.65$. The speed of convergence is computed by using $b=2 \alpha$. To correct for the overestimation of clubs, the $\log (t)$ test is repeated between clubs to check if they can be merged to determine the true emergence of clubs ${ }^{6}$.

\section{E. Testing for Weak Sigma Convergence}

Further, we apply the weak sigma convergence test of Kong et al. (2019) to validate the evidence of consumer price convergence or divergence when the stochastic processes are unknown but exhibit diminishing/increasing trends in variation. The weak sigma convergence test accounts for the panels of asymptotically stationary or weakly dependent series. To test for weak sigma convergence, we determine whether cross-sectional dispersion decays over time, with a trend regression in the following form:

\footnotetext{
6 For further details, see Phillips and Sul $(2007,2009)$.
} 


$$
K_{n t}^{y}=\widehat{\alpha}_{n T}+\widehat{\emptyset}_{n T^{t}}+\widehat{u}_{t}
$$

where $K_{n t}^{y}$ is the cross-sectional sample variation, with $n=1, \ldots, N$ and $t=1, \ldots, T$, and $\hat{u}_{t}$ is the fitted error. Next, we use a $t$-test to check whether the fitted coefficient $\widehat{\emptyset}_{n T}$ is less than zero and statistically significant. A general time decay specification for all $t$ is given by

$$
K_{n t}^{y}=\alpha_{n}+b_{n} t^{-\lambda}+v_{n, t} \geq 0
$$

where $\alpha_{n^{\prime}} b_{n^{\prime}}$ and $v_{n, t}$ embody the individual data generating processes of $y_{i t}$ and the cross-sectional averages contained in $K_{n t}^{y}$ If the convergence parameter $(\lambda)$ is greater than zero, cross-sectional dispersion $\left(K_{n t}^{y}\right)$ will decrease over time under the stability conditions of $n \rightarrow \infty$, which will result in weak sigma convergence. If the convergence parameter is less than zero, cross-sectional dispersion increases over time, indicating that some components of $y_{i t}$ have heterogeneously divergent trend characteristics. Further, when the convergence parameter is equal to zero, there is no tendency to diverge or converge, and $K_{n t}^{y}$ fluctuates around the level of $\alpha$. The standard robust $t$ statistic with a time trend is given by

$$
t_{\widehat{\phi}_{n T}}=\frac{\widehat{\phi}_{n T}}{\sqrt{\widehat{\Omega}_{u}^{2} / \Sigma_{t=1}^{T} \tilde{t}^{2}}}
$$

The presence of weak sigma convergence diverges $t_{\widehat{\phi}_{n T}}$ to $-\infty$. The long-run variance $\left(\widehat{\Omega}_{u}^{2}\right)$ is estimated by the residuals from (15), such as the Bartlett-NeweyWest (BNW) estimate:

$$
\widehat{\Omega}_{u}^{2}=\frac{1}{T} \sum_{t=1}^{T} \widehat{u}_{t}^{2}+2 \frac{1}{T} \sum_{l=1}^{L} v_{l L} \sum_{t=1}^{T-l} \widehat{u}_{t} \widehat{u}_{t}+l
$$

where $v_{l L}$ is the Bartlett lag kernel weight with lag parameter $L=\left[T^{k}\right]$ for $k>0$. The one-sided critical values from a standard normal distribution are considered in testing for evidence of convergence.

There are two broad differences between the approaches of PS and Kong et al. (2019). First, the PS approach implements a $\log (t)$ regression, which considers variation in the cross section among relative transition paths, and a logarithmic trend regression to validate evidence of convergence. Kong et al. (2019), on the other hand, removes any common components in the cross section and implements linear trend regression to find trend decay. In this process, even though the regression is misspecified, the slope coefficient captures the trend decay. 


\section{F. Data}

The consumer price data used in this study were collected from CEIC: Global Economic Database 7 for 82 Indonesian cities for the period of January 2014 to August 2019 at a monthly frequency. We consider the CPI with base year 2012 as a proxy for price. The list of Indonesian cities is given in Appendix (see Table A1).

\section{EMPIRICAL RESULTS}

\section{A. Preliminary Analysis}

The summary statistics for consumer prices across the Indonesian cities are presented in Table 1. The findings show that Tual has the highest mean (139.90) of the 82 cities, and Maumere has the lowest (119.35). Additionally, we see that the standard deviations of the consumer prices of Tual and Kediri have the highest and lowest volatility, respectively, from 2014M1 to 2019M8. The heterogeneity in consumer prices across cities in Indonesia is what motivated this study to examine whether a convergence phenomenon exists in the long run. Next, we plot the CV in Figure 3. It displays evidence of an increasing trend, which implies greater dispersion in the CPI between Indonesian cities over the years. The gap between cities is therefore increasing, suggesting evidence of divergence in consumer prices. In other words, these cities are not following a single transition path.

\section{Figure 3. Coefficient of Variation (CV) over the Years}

This figure displays the coefficient of variation (CV) of price for the period 2014 to 2019. This plot gives the signal about price divergence. The $\mathrm{CV}$ values are measured in terms of percentage.

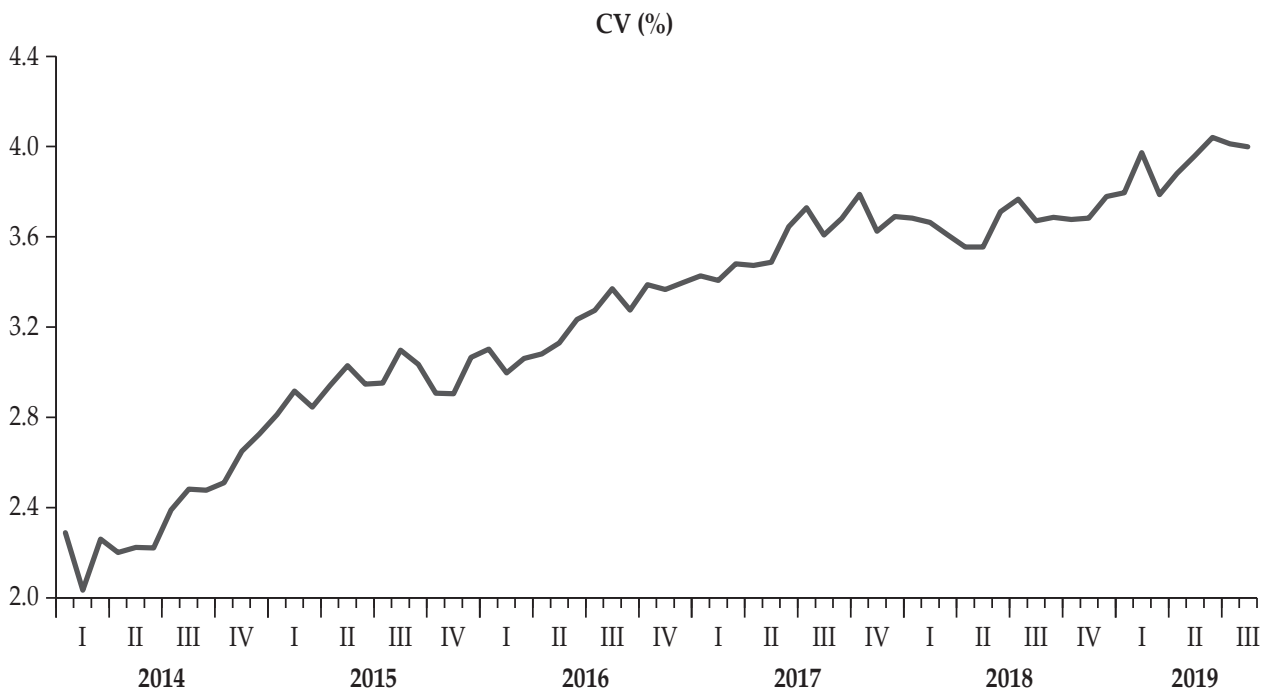

\footnotetext{
7 CEIC Data does not have a full form. For more information, see https://www.ceicdata.com/en.
} 
Further, to validate these results, we employ various panel data models, such as pooled regression panel, fixed dynamic panel, and system GMM panel data models. The results provided in Table 2 show that the coefficients of the lag of consumer prices are positive and significant for all models, which suggests that the variation between countries is increasing, validating the evidence of divergence in Indonesian cities. This finding motivates us to examine whether club convergence exists, where each club has a unique transition path.

Table 2.

Beta Convergence Results

The results of panel data models such as pooled ordinary least square (POLS), fixed-dynamic, and system-GMM are presented in this table. The variable $\ln P_{t-1}$ denotes the logarithm of price with one lag. Finally, ${ }^{* * *}$ indicates the $1 \%$ level of significance. $p$-values are given in the parenthesis.

\begin{tabular}{lccc}
\hline Variable & POLS & Fixed-Dynamic & System-GMM \\
\hline $\ln P_{t-1}$ & $0.99^{* * *}(0.00)$ & $0.98^{* * *}(0.00)$ & $0.98^{* * *}(0.00)$ \\
Constant & $0.06^{* * *}(0.00)$ & $0.08^{* * *}(0.00)$ & $0.09^{* * *}(0.00)$ \\
Sargan test & $\ldots$ & $\ldots$ & $81.96(1.00)$ \\
\hline
\end{tabular}

\section{B. Club Convergence}

We apply the PS test to determine the formation of clubs. The results are presented in Table 3. Since the critical value is greater than the value of $\log (t),-242.98$, for the full sample, we reject the null of convergence. This result suggests that the cities considered do not have a unique transition path. Therefore, PS use a clustering algorithm to form clubs for the cities that have a similar steady state. We find statistically significant four club convergence. Club 1 comprises 10 cities with a $\log (t)$ value of 10.58 , which is evidence of convergence. Club 2 comprises 37 countries, club 3 comprises 27 cities, and club 4 comprises six cities, with $\log (t)$ values of 1.14, 7.82, and 5.59, respectively. Since the critical value is lower than the $\log (t)$ values computed for all the clubs, we do not reject the null of club convergence. Additionally, our results show two cities, Maumere and Tual, that do not converge with any of the above clubs. We thus infer that these two cities have a different transition path compared to the others. 
Table 3.

PS Club Convergence Results

This table reports the PS club convergence results. The $5 \%$ level critical value is 1.65 ; b-hat stands for coefficients, and $\log t$-stat. indicates the $\log t$-statistics.

\begin{tabular}{|c|c|c|c|c|}
\hline Clubs & Cities & $\widehat{\boldsymbol{b}}$ & $\begin{array}{c}\log \\
t \text {-Stat }\end{array}$ & Decision \\
\hline Full samples & All cities & -0.98 & -242.98 & Divergence \\
\hline Club 1 & $\begin{array}{l}\text { Bengkulu, Bulukumba, Cilegon, Palu, } \\
\text { Pangkal Pinang, Pontianak, Serang, } \\
\text { Sibolga, Tanjung Pandan, Tarakan }\end{array}$ & 0.43 & 10.58 & Convergence \\
\hline Club 2 & $\begin{array}{l}\text { Balikpapan, Bandar Lampung, } \\
\text { Bandung, Banjarmasin, Batam, } \\
\text { Bekasi, Bima, Bogor, Bungo, } \\
\text { Cilacap, Depok, Dumai, Jakarta, } \\
\text { Jayapura, Kudus, Makassar, Malang } \\
\text { Manokwari, Medan, Merauke, } \\
\text { Metro, Meulaboh, Padang, Padang } \\
\text { Sidempuan, Palopo, Pekanbaru, } \\
\text { Pematang Siantar, Samarinda, Sampit, } \\
\text { Singaraja, Singkawang,Sukabumi, } \\
\text { Surabaya,Tangerang, Tembilahan, } \\
\text { Ternate, Watampone }\end{array}$ & 0.09 & 1.14 & Convergence \\
\hline Club 3 & $\begin{array}{l}\text { Banda Aceh, Bau-bau, Bukit Tinggi, } \\
\text { Cirebon, Denpasar, Gorontalo,Jambi, } \\
\text { Jember, Kendari, Kupang, } \\
\text { Lhokseumawe, Lubuk Linggau, } \\
\text { Madiun, Mamuju, Manado, } \\
\text { Mataram, Palangkaraya, Palembang, } \\
\text { Purwokerto, Semarang, Sorong, } \\
\text { Sumenep, Tanjung, Tanjung Pinang, } \\
\text { Tasikmalaya, Tegal, Yogyakarta }\end{array}$ & 0.24 & 7.82 & Convergence \\
\hline Club 4 & $\begin{array}{c}\text { Ambon, Banyuwangi, Kediri, Pare- } \\
\text { pare, Probolinggo, Surakarta }\end{array}$ & 1.89 & 5.59 & Convergence \\
\hline Group & Maumere, Tual & -1.38 & -96.75 & $\begin{array}{l}\text { No convergence } \\
\text { and divergence }\end{array}$ \\
\hline \multicolumn{5}{|c|}{ Panel: Merger of Clubs } \\
\hline Club 1+2 & & -0.39 & -8.39 & No merger \\
\hline Club $2+3$ & & -0.46 & -43.54 & No merger \\
\hline Club 3+4 & & -0.13 & -7.45 & No merger \\
\hline Club4+Group & & -1.5 & -123.43 & No merger \\
\hline
\end{tabular}

Next, to identify the true number of clubs, a clustering algorithm is executed between clubs to check whether it is possible to merge clubs into larger clubs. The results in Table 3 indicate that we do not reject the $\log (t)$ value, indicating that no club can be merged to form larger clubs. The presence of four clubs makes an appeal for club-specific policies to achieve overall consumer price convergence. Further, we calculate the speed of convergence for each club. The results presented in Table 4 show that the speeds of convergence for clubs 1 to 4 are, respectively, $0.21 \%, 0.05 \% 0.12 \%$, and $0.95 \%$. We clearly see that the cities in club 4 converge at a faster pace than the other clubs. In Figure 4, we plot the clubs' transition paths 
as determined by the PS technique. The figure shows that each club has a distinct transition path for consumer price convergence.

Table 4.

Club's Speed of Convergence Results

This table reports the speed of convergence for each club.

\begin{tabular}{lc}
\hline Clubs & Speed of Convergence \\
\hline Club 1 & 0.21 \\
Club 2 & 0.05 \\
Club 3 & 0.12 \\
Club 4 & 0.95 \\
\hline
\end{tabular}

\section{Figure 4. Transition Paths of Clubs}

In this figure, we plot the transition path of clubs identified by the PS technique. From this figure, we note that each club has a distinct transition path. The transition paths show the evidence of club convergence in price across the Indonesian cities.

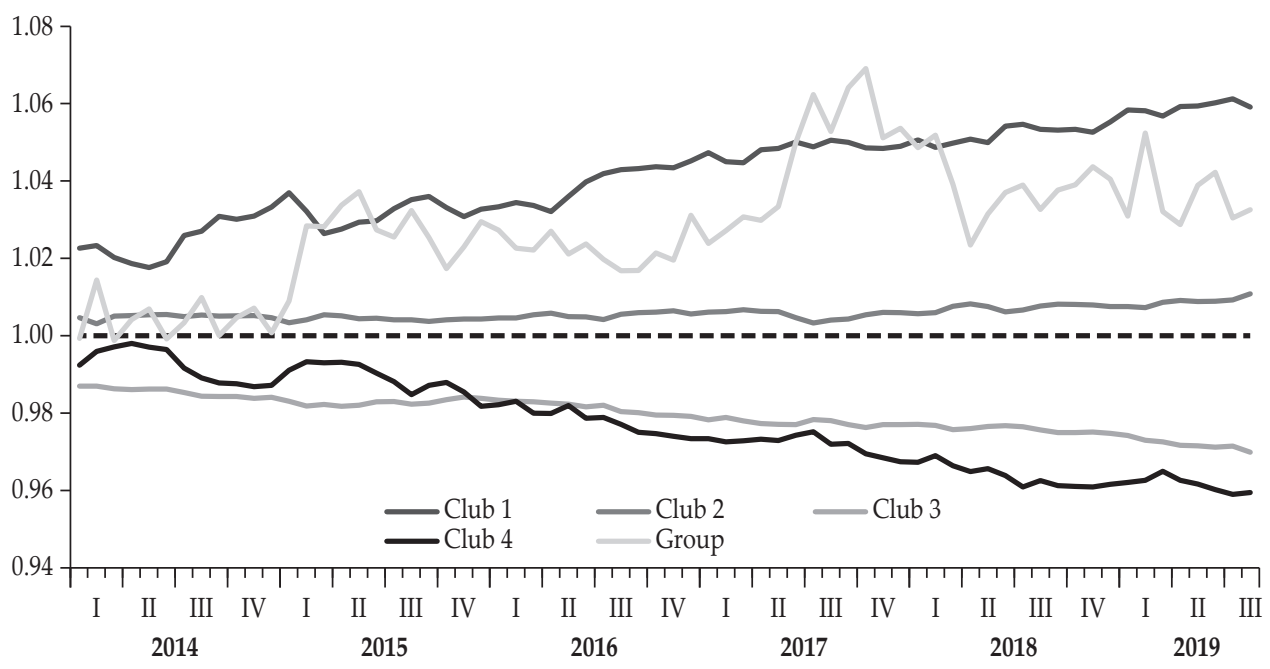

In sum, the results obtained with the PS approach reject evidence of convergence when all cities are taken together. This is because consumer prices in Indonesian cities do not converge to a single steady state; instead, we find four converging clubs. These findings infer that prices in Indonesian cities are vastly heterogeneous, and a unique policy regarding market integration might not, therefore, work well in these cities. Our club convergence results suggest that a club-specific strategy could work better.

The results from the club convergence analysis can be compared to those of Holmes et al. (2019), who note evidence of club convergence for property prices in England and Wales. Our findings contrast with those of Wimanda (2009), who finds overall convergence at the product level in Indonesian cities, suggesting 
a unique policy for market integration. Further, our study differs from that of Bastianin et al. (2019), since they do not find any formation of clubs, but overall convergence of natural gas prices in the European Union. Similar results are found by Tsai I-Chun (2018) for housing prices in euro and non-euro countries.

\section{Testing for Weak Sigma Convergence}

In this section, we implement the weak sigma convergence test recently advanced by Kong et al. (2019) to determine if weak consumer price convergence exists when the cross sections are asymptotically stationary or weakly dependent series. Traditional approaches such as the CV or absolute convergence fail to account for this kind of data behavior and reject the presence of convergence. Further, this test is useful when the stochastic processes are unknown but exhibit diminishing/ increasing trends in variation.

Next, we test for weak sigma convergence. This test includes the common factor $(k)$ and lag truncation parameter settings $\left(t_{\widehat{\phi}_{n T}}\right)$ to construct the long-run variance estimates. If the value of the slope coefficient $\widehat{\emptyset}_{n T}$ is negative and statistically significant for the lag truncation parameter settings and common factors, then the null of no weak sigma convergence is rejected at the $5 \%$ level of statistical significance. Moreover, the weak sigma convergence test differentiates periods of stable, diverging, and converging phases, unlike standard testing approaches, which cannot. Identifying the different phases, controlling for heterogeneity, and incorporating weak dependent panels, we find weak consumer price convergence among Indonesian cities. The results presented in Table 5 show flimsy evidence of sigma convergence. Further, to determine the robustness and stability of the results, we implement an additional seven common factors $(k=2, \ldots, 8)$ and seven lag truncation settings $\left(t_{\widehat{\phi}_{n T}}=2, \ldots, 8\right)$. The choice of common factors and lag truncation can differ from analysis to analysis. They are usually chosen such that the same results are obtained as for the first common factors and lag truncation. Again, the results in Table 5 suggest that the value of the slope coefficient $\widehat{\emptyset}_{n T}$ is negative and statistically significant for all seven lag truncation parameter settings $\left(t_{\widehat{\phi}_{n T}}\right)$ and seven common factors $(k)$. Irrespective of the presence of common factors and lag truncation settings, our results still show weak evidence of consumer price convergence among the 82 Indonesian cities. The evidence of weak sigma convergence suggests that the prices across Indonesian cities adjust, but not freely. The probable reason for the weak sigma convergence involves the price rigidities across the Indonesian cities. Therefore, these cities do not converge to a single steady state; instead, they converge to multiple steady states, as our PS findings show. Possible factors for price rigidities could be differences in transportation costs, levels of development, the logistical costs of goods, non-traded products, firm monopolies, labor market segmentation, informational asymmetries, and productivity (e.g., Tirtosuharto and Adiwilaga, 2013; Varela, et al., 2013). 
Table 5.

Weak Sigma Convergence Results

This table presents the results of weak sigma convergence. $k$ denotes the common factor. $\widehat{\emptyset}_{n T}$ is the coefficient and $t_{\widehat{\phi}_{n T}}$ indicates the $t$-statistics at lags 1 to 8 .

\begin{tabular}{cccccccccc}
\hline $\mathbf{k}$ & $\widehat{\emptyset}_{\boldsymbol{n} \boldsymbol{T}}$ & $\boldsymbol{t}_{\widehat{\phi}_{\boldsymbol{n}}}(\mathbf{1})$ & $\boldsymbol{t}_{\widehat{\phi}_{\boldsymbol{n}}}(\mathbf{2})$ & $\boldsymbol{t}_{\widehat{\phi}_{\boldsymbol{n}}}(\mathbf{3})$ & $\boldsymbol{t}_{\widehat{\phi}_{\boldsymbol{n}}}(\mathbf{4})$ & $\boldsymbol{t}_{\widehat{\phi}_{\boldsymbol{n}}}(\mathbf{5})$ & $\boldsymbol{t}_{\widehat{\phi}_{\boldsymbol{n}}}(\mathbf{6})$ & $\boldsymbol{t}_{\widehat{\phi}_{\boldsymbol{n}}}(\mathbf{7})$ & $\boldsymbol{t}_{\widehat{\phi}_{\boldsymbol{n}}}(\mathbf{8})$ \\
\hline 1 & -0.000018 & -0.0022 & -0.0019 & -0.0017 & -0.0016 & -0.0015 & -0.0015 & -0.0015 & -0.0015 \\
2 & -0.000018 & -0.0022 & -0.0019 & -0.0017 & -0.0016 & -0.0015 & -0.0015 & -0.0015 & -0.0015 \\
3 & -0.000018 & -0.0022 & -0.0019 & -0.0017 & -0.0016 & -0.0015 & -0.0015 & -0.0015 & -0.0015 \\
4 & -0.000018 & -0.0022 & -0.0019 & -0.0017 & -0.0016 & -0.0015 & -0.0015 & -0.0015 & -0.0015 \\
5 & -0.000018 & -0.0022 & -0.0019 & -0.0017 & -0.0016 & -0.0015 & -0.0015 & -0.0015 & -0.0015 \\
6 & -0.000018 & -0.0022 & -0.0019 & -0.0017 & -0.0016 & -0.0015 & -0.0015 & -0.0015 & -0.0015 \\
7 & -0.000018 & -0.0022 & -0.0019 & -0.0017 & -0.0016 & -0.0015 & -0.0015 & -0.0015 & -0.0015 \\
8 & -0.000018 & -0.0022 & -0.0019 & -0.0017 & -0.0016 & -0.0015 & -0.0015 & -0.0015 & -0.0015 \\
\hline
\end{tabular}

\section{Robustness Checking}

To determine the robustness of the clubs formed by the PS approach, we test whether convergence exists among them with a GMM approach. To validate the GMM model, we carry out two tests, specifically, the Sargan test, which checks for overidentification, and the Arellano-Bond test, to determine the presence of autocorrelation. The null hypothesis of the Sargan test is for the instruments as a group to be exogenous. The null hypothesis for the Arellano-Bond test for autocorrelation is 'no autocorrelation'. Acceptance of the null for both tests validates the GMM estimates.

The GMM results are presented in Table 6. The coefficient of consumer price is negative and statistically significant for all four clubs formed by the PS approach. In other words, evidence of convergence is suggested. This infers that consumer prices converge when the cities share common fundamental characteristics. Results are validated by accepting the null of Sargan and autocorrelation tests. The GMM results are consistent with the PS findings.

Table 6.

\section{Generalized Method of Moments Results for Each Club}

This table presents the results of generalized methods of moments (GMM) for each club. The variable $\ln P_{t-1}$ denotes the logarithms of price with one lag. ${ }^{* * *},{ }^{* *}$, and ${ }^{*}$ indicate statistical significance at $1 \%, 5 \%$, and $10 \%$ levels respectively. Finally, $p$-values are given in the parenthesis.

\begin{tabular}{lcccc}
\hline Variables & Club 1 & Club 2 & Club 3 & Club 4 \\
\hline $\ln P_{t-1}$ & $-0.36^{* * *}$ & $-0.40^{* * *}$ & $-0.30^{* * *}$ & $-0.44^{* *}$ \\
& $(0.01)$ & $(0.00)$ & $(0.00)$ & $(0.02)$ \\
Constant & 0.00 & $0.00^{* *}$ & $-0.00^{*}$ & 0.00 \\
& $(0.41)$ & $(0.39)$ & $(0.07)$ & $(0.15)$ \\
Sargan test & 8.24 & 33.01 & 25.95 & 3.93 \\
& $(1.00)$ & $(1.00)$ & $(1.00)$ & $(1.00)$ \\
AR & -0.93 & 0.91 & 1.44 & -1.25 \\
& $(0.35)$ & $(0.36)$ & $(0.15)$ & $(0.21)$ \\
No. Cities & 10 & 37 & 27 & 6 \\
Obs. & 650 & 2405 & 1755 & 390 \\
Wald test & $7.24^{* * *}$ & $732.28^{* * *}$ & $221.22^{* * *}$ & $5.28^{* * *}$ \\
& $(0.01)$ & $(0.00)$ & $(0.00)$ & $(0.00)$ \\
\hline
\end{tabular}




\section{CONCLUSIONS}

Although there are numerous studies examining price convergence, those associated with consumer price convergence across cities are scant. This study provides evidence of consumer price convergence among 82 Indonesia cities using the monthly CPI data over the period from 2014 to 2019. To examine consumer price convergence among these Indonesian cities, we first plot the $\mathrm{CV}$ between them. Further, to explore the results, we employ various panel data models, such as pooled regression panel, fixed dynamic panel, and system GMM panel data models. Second, we use the PS panel club convergence technique to examine different transition paths exist and club formation. Third, to examine convergence in panels of asymptotically stationary or weakly dependent series and determine whether there is weak overall convergence among Indonesian cities, we employ a novel technique recently proposed by Kong et al. (2019).

The findings are summarized as follows. First, the CV shows increasing price variability and dispersion among Indonesian cities over the years. The panel data models also yield the same results. Second, the results obtained through the PS approach reject the evidence of overall convergence, suggesting that consumer prices in Indonesian cities do not converge to a single steady state. Further, when cross sections are grouped into clubs based on long-run characteristics, we note four statistically significant converging clubs and a diverging group, indicating four different consumer price convergence paths in Indonesian cities. The speed of convergence among clubs 1 through 4 are found be $0.21 \%, 0.05 \% 0.12 \%$, and $0.95 \%$, respectively, suggesting that the cities in club 4 converge at a faster pace than in the other clubs. Third, the results obtained from Kong et al. (2019) test reveal weak consumer price convergence among Indonesian cities. This finding suggests that, although there are heterogeneities in consumer prices across Indonesian cities, the prices adjust, but not freely, indicating that the markets are becoming integrated.

From a policy perspective, our findings suggest that consumer prices among Indonesian cities adjust, but not freely, due to price rigidities that can be reduced by targeting transportation costs, uncertainty, and information costs. Since there is weak consumer price convergence, the forecasted consumer prices might not be robust. Additionally, policy should consider unique convergence paths for each club to obtain stronger consumer price convergence. Overall, this study provides different strategies to model convergence patterns.

Acknowledgments: The authors thank the editor Prof. Paresh Kumar Narayan and two anonymous referees for providing valuable suggestions, which improved this paper substantially. The usual disclaimer applies.

\section{REFERENCES}

Afin, A. (2006). Convergence in price level among east Java's regions. Buletin Ekonomi Moneter dan Perbankan, 8, 1-16.

Allington, N.F.B., Kattuman, P.A., \& Waldmann, F.A. (2005). One Market, One Money, One Price? International Journal of Central Banking, 1, 73-115.

Arellano, M., \& Bond, S. (1991). Some Tests of Specification for Panel Data: Monte Carlo Evidence And an Application to Employment Equations. Review of Economic Studies, 58, 277-297. 
Arellano, M., \& Bover, O. (1995). Another Look at the Instrumental Variables Estimation Of Error-Components Models. Journal of Econometrics, 68, 29-51.

Arruda, E. F., Castelar, V., Guimarães, D. G., \& Barbosa, R. B. (2018). Price Convergence, Reversal Speed, and Purchasing Power Parity: Stylized Facts for Brazilian Cities. Economia, 19 , 219-235.

Asplund, M., \& Friberg, R. (2001) The Law of One Price in Scandinavian Duty-Free Stores. American Economic Review, 91, 1072-1083.

Bastianin A., Marzio G., \& Michele P. (2019). Convergence of European Natural Gas Prices. Energy Economics, 81, 793-811.

Blundell, R., \& Bond, S. (1998). Initial Conditions and Moment Restrictions in Dynamic Panel Data Models. Journal of Econometrics, 87, 115-143.

Castellacci, F., \& Archibugi, D. (2008). The Technology Clubs, the Distribution of Knowledge Across Nations. Research Policy, 37, 1659-1673.

Cecchetti, G.S., Mark, N. C., \& Sonora, R. J. (2000). Price index convergence among United States cities. International Economic Review, 43, 1081-1099.

Chmelarova, V., \& Nath, H. K. (2010). Relative Price Convergence Among US Cities: Does the Choice of Numeraire City Matter? Journal of Macroeconomics, 32, 405-414.

Churchill, S. A., Inekwe, J., \& Ivanovski, K. (2018). House price convergence: Evidence from Australian cities. Economics Letters, 170, 88-90.

Coleman, A., \& Daglish, T. (1998). Regional Price Convergence in Australia and New Zealand, 1984-1996. Treasury Working Paper Series 98/03, New Zealand Treasury. Competitiveness, MIT Press, Cambridge, 149-179.

Cuaresma, J.C., Égert, B., \& Silgoner, M., A. (2007). Price Level Convergence in Europe: Did the Introduction of the Euro Matter? Monetary Policy and the Economy, Oesterreichische Nationalbank (Austrian Central Bank), 1,100-113.

Cuaresma, J.C., Hlouskova, J., \& Obersteiner, M. (2008). Natural Disasters as Creative Destruction? Evidence from Developing Countries. Economic Inquiry, 46, 214-226.

Dalgaard, C.-J., \& Vastrup, J. (2001). On the Measurement of $\sigma$-Convergence. Economics Letters, 70, 283-287.

Tirtosuharto, D., \& Adiwilaga, H. (2013). Decentralization and regional inflation in Indonesia. Bulletin of Monetary Economics and Banking, Bank Indonesia, 16(2), 1-18.

Das, S., Bhattacharya, K. (2008). Price Convergence Across Regions in India. Empirical Economics, 34, 299-313.

Engel, C. \& Rogers, J. H. (2004). European Product Market Integration after the Euro. Economic Policy, 19, 347-384.

Engel, C., \& Rogers, J. (2001). Violating the Law of One Price: Should We Make a Federal Case Out of It? Journal of Money, Credit, and Banking, 33, 1-15.

Engel, C., \& Rogers, J.H. (1996). How Wide Is the Border? The American Economic Review, 86, 1112-1125.

Engel, C. (1993). Real Exchange Rates and Relative Prices. Journal of Monetary Economics, 32, 35-50.

Faber, R.P., \& Stokman, A.C.J. (2009). A short History of Price Level Convergence in Europe. Journal of Money, Credit and Banking, 41, 461-477. 
Fischer, C. (2012). Price convergence in the EMU? Evidence from microdata. European Economic Review, 56 , 757-776.

Fischer, C. (2010). An Assessment of the Trends in International Price Competitiveness Among EMU Countries. Dimensions of competitiveness, 149-179, Paul de Grauwe, ed., MIT Press.

Gheorghe, M., \& Vasile, V. (2015). Price Convergence in Romania - Statistical Evaluation. Procedia Economics and Finance, 32, 367-375.

Guerreiro, D., \& Mignon, V. (2013). On price convergence in Eurozone. Economic Modelling, 34, 42-51.

Hałka, A., \& Leszczynska-Paczesna, A. (2018) Price convergence in the European Union - What has Changed? Economic Modelling, 79, 226-241.

Hegwood, N. D., Nath, \& Hiranya K. (2013). Structural Breaks and Relative Price Convergence among US Cities. Journal of Macroeconomics, 36, 150-160.

Hill, R. J. (2004). Constructing Price Indexes Across Space and Time: The Case of the European Union. The American Economic Review, 94, 1379-1410.

Holmes, J. M., Jesús O., \& Theodore P. (2019). Property Heterogeneity and Convergence Club Formation among Local House Prices. Journal of Housing Economics, 43, 1-13.

Hotelling, H. (1933). Review of the Triumph of Mediocrity in Business by Horace Secrist. Journal of the American Statistical Association, 28, 463-465.

Huang, H. C., Liu, W. H., \& Yeh, C. C. (2012). Convergence in Price Levels across US Cities. Economics Letters, 114, 245-248.

Isard, P. (1977). How Far Can We Push the Law of One Price? American Economic Review, 67, 942-948.

Kim, H., \& Ryu, D. (2015). Measuring the Speed of Convergence of Stock Prices: A Nonparametric and Nonlinear Approach. Economic Modelling, Elsevier, 51, 227-241.

Kim, Y. S., \& Rous, J. J. (2012). House price convergence: Evidence from US state and metropolitan area panels. Journal of Housing Economics, 21, 169-186.

Kitenge, M. E., \& Morshed. A.K.M.M. (2019). Price Convergence Among Indian Cities: The Role of Linguistic Differences, Topography, and Aggregation. Journal of Asian Economics, 61, 34-50.

Kong J., Phillips, P. C. B., \& Sul, D. (2019). Weak $\sigma$-convergence: Theory and Applications. Journal of Econometrics, 209, 185-207.

Liddle, B. (2009). Electricity Intensity Convergence in IEA/OECD Countries: Aggregate and sectoral Analysis. Energy Policy, 37, 1470-1478.

Liddle, B. (2010). Revisiting World Energy Intensity Convergence for Regional Differences. Applied Energy, 87, 3218-3225.

Lutz, M. (2004). Price Convergence under EMU? First estimates in: Deardorff, A.V. (Ed.), The Past, Present and Future of the European Union, Palgrave MacMillan, Basingstoke, 48-73.

Miketa, A., \& P. Mulder. (2005). Energy Productivity Across Developed and Developing Countries in 10 Manufacturing Sectors: Patterns of Growth and Convergence. Energy Economics, 27, 429-453.

Montañés, A., \& Olmos, L. (2013). Convergence in US House Prices. Economics Letters, 121, 152-155. 
Morshed, A., S. Ahn, \& M. Lee. (2006). Price Convergence Among Indian Cities: A Cointegration Approach. Journal Of Asian Economics, 17, 1030-1043.

Maryaningsih, N.O.H., \& Savitri, M. (2014). Pengaruh Infrastruktur Terhadap Pertumbuhan Ekonomi Indonesia. Bulletin of Monetary Economics and Banking, Bank Indonesia, 17, 1-38.

Narayan, P.K., Sagarika, M., \& Narayan, S. (2011). Do Market Capitalization and Stocks Traded Converge? New Global Evidence. Journal of Banking and Finance, 35, 2771-2781.

Parsley, D., \& Wei, J. (1996). Convergence to the Law of One Price Without Trade Barriers or Currency Fluctuations. Quarterly Journal of Economics, 111, 1211-36.

Phillips, P. C. B., \& Donggyu Sul. (2007). Transition Modeling and Econometric Convergence Tests. Econometrica 75, 1771-1855.

Phillips, P. C. B., \& Sul, D. (2009). Economic Transition and Growth. Journal of Applied Econometrics, 24, 1153-1185.

Purwono, R., \& Yasin, M.Z. (2018). The Convergence Test of Indonesia Banking Inefficiency: Do Macroeconomic Indicators Matter? Bulletin of Monetary Economics and Banking, 21, 1 -16.

Quah, D. (1993). Empirical Cross-Section Dynamics in Economic Growth. European Economic Review, 37, 426-434.

Ratfai, A. (2003). How Fast is Convergence to the Law of One Price? Very (when Price Differentials Are Properly Measured). Central European University. (Unpublished manuscript).

Rath, B., N. (2019). Does Total Factor Productivity Converge among ASEAN Countries? Bulletin of Monetary Economics and Banking, 21, 1-18.

Rath and Akram (2019). A Reassessment of Total Factor Productivity Convergence: Evidence from Cross-Country Analysis. Economic Modelling (in press). https:// doi.org/10.1016/j.econmod.2019.08.002

Ram, R., (2017). Comparison of Cross-Country Measures of Sigma Convergence in Per-Capita Income, 1960-2010, Applied Economics Letters 25, 1010-1014.

Rogers, J. H. (2007). Monetary Union, Price Level Convergence, and Inflation: How Close is Europe to the USA? Journal of Monetary Economics, 54, 785-796.

Saygili, H. (2017). Production Fragmentation and Factor Price Convergence. International Review of Economics and Finance, 51, 535-544.

Sonora, R. (2009). City Relative Price Convergence in the USA with Structural Break(s). Applied Economics Letters, 16, 939-944.

Tsai I-Chun. (2018). House Price Convergence in Euro Zone and Non-Euro Zone Countries. Economic Systems, 42, 269-281.

Varela, G., Aldaz-Carroll, E., \& Iacovone, L. (2013). Determinants of Market Integration and Price Transmission in Indonesia. Journal of Southeast Asian Economies, 30, 19-44.

Wimanda, Rizki E. (2009). Price Variability and Price Convergence: Evidence from Indonesia. Journal of Asian Economics, 20, 427-442.

Wood, G., Sommervollde, D. E., \& Silva, A. (2015). Do Urban House Prices Converge? Urban Policy and Research, 34, 102-115.

Yazgan, E., \& Yilmazkuday, H. (2011). Price-level Convergence: New Evidence from U.S. Cities. Economics Letters, 110, 76-78. 


\section{Appendix}

Table A1.

\section{List of the Indonesian Cities}

List of the cities of Indonesia are presented in this table. We total have 82 cities.

\section{List of the Indonesian Cities}

Ambon, Balikpapan, Banda Aceh, Bandar Lampung, Bandung, Banjarmasin, Banyuwangi, Batam, Bau-bau, Bekasi, Bengkulu, Bima, Bogor, Bukit Tinggi, Bulukumba, Bungo, Cilacap, Cilegon, Cirebon, Denpasar, Depok, Dumai, Gorontalo, Jakarta, Jambi, Jayapura, Jember, Kediri, Kendari, Kudus, Kupang, Lhokseumawe, Lubuk Linggau, Madiun, Makassar, Malang, Mamuju, Manado, Manokwari, Mataram, Maumere, Medan, Merauke, Metro, Meulaboh, Padang, Padang Sidempuan, Palangkaraya, Palembang, Palopo, Palu, Pangkal Pinang, Pare-pare, Pekanbaru, Pematang Siantar, Pontianak, Probolinggo, Purwokerto, Samarinda, Sampit, Semarang, Serang, Sibolga, Singaraja, Singkawang, Sorong, Sukabumi, Sumenep, Surabaya, Surakarta, Tangerang, Tanjung, Tanjung Pandan, Tanjung Pinang, Tarakan, Tasikmalaya, Tegal, Tembilahan, Ternate, Tual, Watampone, Yogyakarta. 
This page is intentionally left blank 